\title{
EDITORIAL
}

\section{Tax reform plays politics with doctors' reputations}

\author{
Matthew B. Stanbrook MD PhD
}

— Cite as: CMAJ 2017 October 2;189:E1249. doi: 10.1503/cmaj.171132

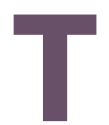

he federal government is proposing to eliminate several tax advantages that incorporated small businesses use to help offset risk and plan for the future. Most medical practices operate as small businesses. Provincial governments have recognized this by giving physicians the right to incorporate - indeed, some have actively encouraged physicians to do so - and many physicians in Canada are incorporated.

Ideally, a policy discussion about tax reform ought to be a technocratic yet thoughtful and respectful weighing of pros and cons. Disappointingly, it has become a hyperbolic, highly politicized battle among vested interests for the hearts and minds of Canadians. The government has maligned the reputation of small business owners - especially physicians. Small business owners and their representatives, including physician organizations, have been fiercely critical.

Government is mostly to blame for how this issue has unfolded. Federal Minister of Finance Bill Morneau prefaced the release of the proposal document with the accusation that "the richest Canadians are unfairly exploiting the tax rules" and the document itself refers repeatedly to owners of private corporations as avoiding

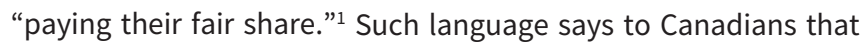
small business owners - including physicians - routinely evade taxes and cheat the public purse.

The evolving discourse has targeted physicians specifically. Prime Minister Justin Trudeau charged opposition critics of the proposed tax changes with standing up for interests of physicians - as if supporting physicians were a bad thing - then sought to set health professionals against one another with the dubious assertion that doctors pay lower taxes than nurses. ${ }^{2}$ Such rhetoric defines physicians, in the public mind, as members of a wealthy elite who exploit the system. It implies that Canadians should not care about anything the government does to physicians. The damage that this portrayal could pose to the reputation of physicians and public trust in our profession represents a far more serious and potentially longer-lasting threat than the financial impact of any tax changes - one that could in turn damage the quality of health care that Canadians receive.

Debate over this tax policy should not be centred around physicians at all, given that we represent a small fraction of private corporations in Canada. However, physicians have been vocal, highlighting our long years of study and hard work, our often massive student debt, our lack of pensions and other benefits, and the potential barriers these pose for women in their child-bearing years in particular all are valid concerns. Yet the most salient argument may be this: it is harsh and unnecessary for the government to load extra stress onto an already overworked profession, merely to prove itself a champion of the middle class. To do so risks increasing the burnout already prevalent among physicians, or even driving smart young Canadians away from medical careers altogether.

Some physicians endorsed the proposed tax changes in an open letter to Morneau ${ }^{3}$ in defence of a more equitable tax base that could be used to address social determinants of health. Their perspective, in stark contrast to the government's reckless language and combative approach, reminds us that health advocacy is a core value and a professional expectation for all physicians. Even so, an endorsement of the government's position seems frankly naive, given that the proposed tax changes would, at best, represent a fraction of what would constitute an equitable overhaul of the tax system.

There is room within our profession for diverse perspectives on issues that affect us. We must respect one another and maintain common ground. Too often, on political issues that affect our income, Canadian physicians have been hobbled of late by infighting, coercion and even bullying. ${ }^{4}$ This is counterproductive, at odds with our professional values and must stop. Physicians must engage in a respectful dialogue, both with government and among ourselves, to address the proposed tax reforms. To ensure space for respectful conversation, the government should extend the brief public consultation period allotted for its proposal and stop tarnishing the medical profession as political cover to advance its agenda.

\section{References}

1. Tax planning using private corporations. Ottawa: Department of Finance Canada; 2017. Available: https://www.fin.gc.ca/activty/consult/tppc-pfsp-eng.pdf (accessed 2017 Sept. 22).

2. Wherry A. In tax fight, it's Scheer's mechanic vs. Trudeau's doctor. CBC News 2017 Sept. 18. Available: www.cbc.ca/news/politics/trudeau-scheer-question-period -tax-analysis-wherry-1.4295500 (accessed 2017 Sept. 22).

3. An open letter to Minister Morneau from more than 450 physicians and medical students. Available: https://docsandtaxes.wordpress.com/ (accessed 2017 Sept. 22).

4. Boyle T. Ontario doctors 'distressed' over wave of bullying, infighting. Toronto Star 2017 Feb. 27. Available: https://www.thestar.com/life/health_wellness/2017/02/27 /ontario-doctors-distressed-over-wave-of-bullying-infighting.html (accessed 2017 Sept. 22).

Competing interests: See www.cmaj.ca/site/misc/cmaj_staff.xhtml. Matthew Stanbrook is not incorporated, nor is any member of his family.

Affiliation: Deputy Editor, CMAJ

Correspondence to: CMAJ editor, pubs@cmaj.ca 